WIELKIE TEMATY KULTURY W LITERATURACH SKOWIAŃSKICH

Slavica Wratislaviensia CLXVIII • Wrocław 2019•AUWr No 3875

DOI: 10.19195/0137-1150.168.27

Data przesłania artykułu: 7.09.2017

Data akceptacji artykułu: 5.12.2017

AGATA FIRLEJ

Uniwersytet im. Adama Mickiewicza w Poznaniu, Polska

\title{
Śmierć porwana. O terezińskiej sztuce Hledáme strašidlo Hanuša Hachenburga z 1943 roku
}

Hledáme strašidlo to siedmioaktowa sztuka przeznaczona dla teatru kukiełkowego, napisana w getcie Terezinie w 1943 roku przez czternastoletniego Hanuša Hachenburga, który rok później zginął w Auschwitz. Utwór nie został nigdy wystawiony $\mathrm{w}$ getcie ${ }^{1}$, odbywały się najprawdopodobniej jedynie próby czytane. Po wojnie tekst przeleżał kilkadziesiąt lat w archiwach, aż pod koniec lat dziewięćdziesiątych zainteresował się nim inscenizator teatralny Gary Friedman, który w 2001 roku wystawił go w Kapsztadzie jako Looking for a Monster, a później nakręcił film dokumentalny o losach dzieła i jego autora. W 2008 roku amerykańska slawistka Lisa Peschel umieściła go w dwujęzycznej antologii Divadelni texty z terezinského ghetta 1941-1945/Theatertexte aus dem Ghetto Theresienstadt 1941-1945 z przekładem na niemiecki Michaela Wögerbauera i w ten sposób symbolicznie tekst wrócił do Czech.

W alegorycznej historii nakreślonej przez Hachenburga Król-tyran chce raz na zawsze zlikwidować u swoich poddanych rewolucyjne tendencje i skłonność do samodzielnego myślenia. Cel precyzuje tak: „Nutno vše zaříditi tak, aby lid był přesvědčen, že co bylo, je dobré. Naši předchůdci vládli klidně a v pokoji a lid se nevzpouzel”2. Z podpowiedzią co do sposobu spieszy Minister: „Po-

${ }^{1}$ Wbrew informacji umieszczonej przez Hanuša Hachenburga pod tytułem tekstu w rękopisie: „Konkurz časopisu Vedem, Terezín, Ha- ”, sztuka w rzeczywistości nie brała udziału w żadnym konkursie — była to najprawdopodobniej jeszcze jedna spośród wielu artystycznych mistyfikacji autorstwa młodych mieszkańców getta, których łączyło mieszkanie w tym samym budynku i wspólnie tworzony almanach „Vedem”. Dopisek „Ha-” to skrót od nazwiska autora.

${ }^{2}$ H. Hachenburg, Hledáme strašidlo, [w:] Divadelní texty z terezinského ghetta 1941-1945/ Theatertexte aus dem Ghetto Theresienstadt 1941-1945, red. L. Peschel, Praha 2008, s. 135. 
třebujeme strašidlo”, , a także Policjant: „Smrt. Kostru. Té se lidé nejvíc bojî”4. Wątek śmierci uprowadzonej przez władcę jest znany już z mitologii: z opowieści o królu Syzyfie, ale i o królowej Alcestis, umierającej w zamian za męża i „odbitej” śmierci przez Heraklesa. Przeniknął on także do kultury ludowej, w polskim teatrze wykorzystany przez Witolda Wandurskiego w sztuce Śmierć na gruszy z 1923 roku, która, co znamienne, miała znacznie lepszą recepcję w teatrze w Brnie niż w Krakowie. Opowieści mitologiczne, ludowe i literackie łączy wątek bohatera unieszkodliwiającego śmierć, próbującego nad nią zapanować, odebrać jej władzę. W czasie wojny niektórzy artyści kojarzyli ten motyw ze zbrodniami nazistów: Nelly Sachs opublikowała w późnych latach czterdziestych wiersz In den Wohnungen des Todes (1947) z podtytułem Dein Leib in Rauch durch den Luft, w którym określenie „złodzieje śmierci” odnosi się właśnie do ludzi Hitlera: „O ihr Räuber von echten Todesstunden,/ Letzten Atemzügen und der Augenlider/ Gute Nacht” [„O wy, złodzieje autentycznych godzin śmierci / Ostatnich westchnień, zamkniętych powiek/ dobrej nocy" — przeł. A. F.] $]^{5}$.

W sztuce Hachenburga wszystko zaczyna się od śmierci zmistyfikowanej, „podrobionej” z kości i szmat, ale nawet sam falsyfikat wystarcza, by dokonać rzeczywistych zmian w społeczeństwie. Król, jak każdy populista, okazuje się mistrzem hochsztaplerki. Prawdziwa Śmierć wkrótce sama przychodzi do pałacu na skargę, przerażona „dziwnymi czasami”, które nastały: demoralizacją ludzi dobrowolnie oddających jej nawet swoich najbliższych: „To je hrůza, milostpaní, s těma kostma. [...] To jsou divný časy”6. W pewnym sensie pierwsza „kradzież” śmierci, a dokładniej: części jej prerogatyw, nastąpiła właśnie na samym początku sztuki: władca zaburza dotychczasowy ład moralny, skłaniając poddanych, by porzucali wartość bliższą (rodzina, miłość, człowieczeństwo) na rzecz sfalsyfikowanej wartości wyższej (powrót do „złotego wieku”, poczucia spokoju, bezpieczeństwa). Podobny motyw znajdujemy w napisanej mniej więcej w tym samym czasie w Terezinie niemieckojęzycznej operze Petera Kiena i Viktora Ullmanna Der Keiser von Atlantis oder die Tod-Verweigerung (Cesarz Atlantydy albo niepostuszeństwo Śmierci) ${ }^{7}$. Dzieło to również nie zostało w getcie pokazane, ale Hachenburg mógł o nim usłyszeć od współwięźniów i inspirować się nim podczas pisania swojej sztuki, zwłaszcza że oprócz wątku unieszkodliwionej śmierci utwory łączy też podobieństwo niektórych postaci i subtelne nawiązania do konwencji commedia dell'arte. Śmierć u Kiena i Ullmanna skarży się, że władca wszedł w jej kompetencje (,odbieranie ludziom życia to moja praca, a nie jego!”),

${ }^{3}$ Ibidem.

${ }^{4}$ Ibidem.

${ }^{5}$ Cyt. za: Nelly Sachs, The Poetics of Silence and the Limits of Representation, oprac. E. Martin, Berlin 2011, s. 84.

${ }^{6}$ H. Hachenburg, Hledáme strašidlo..., s. 137.

7 Jednoaktowa opera, napisana około 1943 roku, została ocenzurowana przez nazistowskich zarządców Terezina ze względu na bezpośrednie odniesienia do Hitlera i jego zwolenników. Pokazano ją po raz pierwszy dopiero w 1975 roku w Amsterdamie. 
a „zmechanizowane rydwany wojny” zbierające śmiertelne żniwo z niespotykaną dotąd intensywnością odbierają jej satysfakcję z pracy i wyczerpują fizycznie; w końcu decyduje się na strajk.

Śmierć ze sztuki Hachenburga idzie rozmówić się z Królem, ten jednak aresztuje ją, widząc szansę na wzmocnienie swojego wpływu. Używa przy tym urzędowego języka, podobnie jak Śmierć w operze Kiena i Ullmanna, co należy odczytywać jako aluzję do zbiurokratyzowanego hitlerowskiego systemu: „Jste zatčena. [...] Angažuji vás jako své státní strašidlo. Váš rajon vám ihned

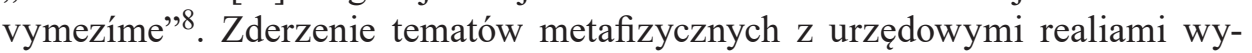
wołuje efekt komiczny, znany czeskiemu odbiorcy już choćby z lektury Karla Havlička Borovskiego - który, notabene, chętnie był przez terezińskich artystów przypominany. Król sądzi, że lęk przed prawdziwą Śmiercią zagwarantuje większą podatność słuchaczy na demagogię: i rzeczywiście, plan ten udaje się przeprowadzić nadzwyczaj łatwo, nie ma w tej sztuce ani jednej postaci, która nie poddałaby się hipnotycznej i demoralizującej sile ideologii. Hachenburg pokazuje, w jaki sposób „uprowadzenie śmierci” przez uzurpatora zaburza porządek moralny w całym społeczeństwie ${ }^{9}$. Namysł nad istotą i konsekwencjami wstrząsu etycznego można wyczytać także w niektórych tekstach umieszczanych przez niego w „Vedem”, almanachu konspiracyjnie współtworzonym przez chłopców z tak zwanej Republiki Škid, czyli jednego z terezińskich gmachów, w którym wspólnie mieszkali i się uczyli. Pisał:

Společenský mrav — chování se dle předpisů - je pozůstatek z doby králů, knížat a císařò. [...] Společenský mrav je výsadou těch, kteří trpí nadbytkem a mají čas na přetvářku. Mají na něm zájem ti, kteří si chtějí pro vlastní nic zaručiti jistou autoritu. V Terezíně se poměry od základů změnily. Nikdo nemá čas na dlouhé fráze, at’ jakékoliv, když má hlad. Nikdo nemá čas, aby snad se přesvědčil, zda se sluší oslovit dívku na ulici a požádat ji o informaci, čili nikoliv. Projevil se zde každý tak, jak je, bez masky. Jsou zde př́́klady nejvystupňovanějšího egoismu. To neudělal Terezín, to se ukázala pravá tvár ${ }^{10}$.

Ta diagnoza zbiorowego życia, wywiedziona przez Hachenburga z obserwacji w getcie i rozmów ze współwięźniami, brzmi jak echo przedwojennych zapisków Nadieżdy Mandelsztam (o społecznym zdziczeniu w sowieckiej Rosji) albo — przenosząc konstatacje na poziom jeszcze ogólniejszy — wiedeńskich wykładów Roberta Musila z lat trzydziestych. W 1937 roku Musil wyjaśniał:

Man spricht heute vielfach von einer Vertrauenskrisis der Humanität, einer Krisis des Vertrauens, das bis jetzt noch in die Menschlichkeit gesetzt wird; sie ließe sich auch eine Panik

${ }^{8}$ H. Hachenburg, Hledáme strašidlo..., s. 137.

${ }^{9} \mathrm{Na}$ początku wieku Reiner Maria Rilke pisał w jednym z wierszy podobnie o ,własnej śmierci”: „Herr, gib jedem seinen eignen Tod./Das Sterben, das aus jenem Leben geht,/darin er Liebe hatte, Sinn und Not”, R. M. Rilke, Das Buch von der Armut und vom Tode (1903). [„,Każdemu daj śmierć jego własną, Panie,/daj umieranie, co wynika z życia,/gdzie miał swą miłość, cel i biedowanie", cyt. za: J. Tischner, Świat ludzkiej nadziei, Kraków 2000, s. 263-264].

${ }^{10} \mathrm{H}$. Hachenburg [Ha], tekst pochodzi z almanachu „Vedem”, s. 117, www.vedem-terezin. cz [dostęp: 1.09.2017]. 
nennen, die im Begriffe ist, an die Stelle der Sicherheit zu treten, daß wir imstande seien, unsere Angelegenheiten in Freiheit und mit Vernunft zu führen. Und wir dürfen uns nicht darin täuschen, daß diese beiden sittlichen, und auch sittlich-künstlerischen Begriffe, Freiheit und Vernunft, die als Wahrzeichen der Menschenwürde aus dem klassischen Zeitalter der deutschen Weltbürgerlichkeit auf uns gekommen sind, schon seit der Mitte des neunzehnten Jahrhunderts oder einem wenigen später nicht mehr so ganz bei Gesundheit gewesen sind. [Wiele mówi się dzisiaj o kryzysie zaufania do humanizmu, o kryzysie zaufania, jakiego ludzkość do tej pory nie doświadczyła; można wręcz mówić o panice, która próbuje zastąpić pewność, że jesteśmy w stanie korzystać z naszego rozumu i z wolności. Nie oszukujmy się: oba te pojęcia, przynależne do porządku moralnego i artystycznego, wolność i rozum, które zwykliśmy uważać za wyróżniki człowieczeństwa, już od połowy dziewiętnastego stulecia mają się niezbyt dobrze - przeł. A. F. $]^{11}$.

Na dwa lata przed wybuchem wojny Musil mówił o panice jako nowym paradygmacie życia społecznego; panika, której składnikiem był brak wiary w przyszłość, a paliwem nostalgia za nieistniejącymi „dawnymi, dobrymi czasami”, okazała się niebezpiecznym narzędziem w rękach demagogów.

Lęk przed przyszłością — wywołany i symbolizowany przez Śmierć-Straszydło w omawianej sztuce Hanuša Hachenburga — ma skłonić ludzi do gloryfikacji przeszłości, ale nie przeszłości dowolnej, tylko skonstruowanej retroaktywnie przez władcę, który doskonale wie, że: „Potřebujeme ne lidi nemyslící, ale myslící, a to tak, jak si to přeji"12. Krótko mówiąc, u Hachenburga Śmierć ma służyć Królowi do wcielania w życie retrotopii, tęsknoty za wyidealizowaną przeszłością.

Refleksja naukowa nad zjawiskiem określanym jako retrotopia właściwie dopiero się rozpoczyna pod patronatem Zygmunta Baumana, ale w dyskursie społecznym i w sztuce istnieje ono od dawna; jego podstawowy budulec, nostalgia, zwykle poprzedza rewolucje, jak dowodzi harvardzka slawistka i komparatystka Swietłana Boym. Badaczka podaje jako przykład rewolucję francuską, argumentując: „Not only the ancien régime produced revolution, but in some respect the revolution produced the ancien régime, giving it a shape, a sense of closure and a gilded aura” [„Nie tylko ancien régime stworzył rewolucję, ale pod pewnymi względami to rewolucja stworzyła ancien régime, nadając jej kształt, zamkniętą formę i blichtr" - przeł. A. F. ${ }^{13}$. Odczytywana w takiej optyce sztuka Hachenburga opowiada analogiczną historię o tym, jak hitleryzm został wykreowany i zarazem sam wykreował obraz minionej i niesprawiedliwie zmiażdżonej wielkości Rzeszy, do której trzeba powrócić. Król Analfabet Huba dzieli z Adolfem Hitlerem nie tylko inicjały i temperament, lecz także retrotopiczną strategię.

We wprowadzeniu do Retrotopii, ostatniej książki Zygmunta Baumana, znajdujemy próbę zdefiniowania tego zjawiska w kontekście utopii:

11 R. Musil, Über die Dummheit [rozdz. 2], http://gutenberg.spiegel.de/buch/-6885/2 [dostęp: 2.09.2017].

${ }^{12}$ H. Hachenburg, Hledáme strašidlo..., s. 135.

13 Cyt. za: Z. Bauman, Retrotopia, Cambridge-Malden 2017, s. 10. 
What I call 'retrotopia', is a [...] negation of utopia's negation, one that shares with Thomas More's legacy its fixity on a territorially sovereign topos: a firm ground thought to provide, and hopefully guarantee, an acceptable modicum of stability and therefore a satisfactory degree of self-assurance. [...] True to the utopian spirit, retrotopia derives its stimulus from the hope of reconciling, at long last, security with freedom; the feat that both the original vision and its first negation didn't try — or, having attempted, failed — to attain. [Retrotopią nazywam negację negacji utopii, którą łączy z wizją Thomasa More'a usytuowanie na terytorium toposu, solidnym gruncie gwarantującym odpowiedni poziom samo-upewnienia. [...] Choć utrzymana w prawdziwie utopijnym duchu, retrotopia rezygnuje z nadziei na uzdrowienie, bezpieczeństwo i wolność, których utopia i jej negacja — mimo prób — nie osiągnęły — przeł. A. F. $]^{14}$.

Retrotopia jest zawieszona między utopią i antyutopią: z jednej strony odwołuje się do retroaktywnie zmanipulowanej i opowiedzianej na nowo przeszłości jak do wizji utopijnej, z drugiej strony: jej siłą napędową jest — w odróżnieniu od utopii - absolutna niewiara w postęp i świadomość prognoz, z których wynika, że przyszłość będzie gorsza niż przeszłość i teraźniejszość ${ }^{15}$. Przyszłość jest jak dantejskie piekło, opatrzone klasycznym ostrzeżeniem: „porzućcie wszelką nadzieję, którzy tu wchodzicie". Metaforą piekła posługuje się też Bauman, rozpoczynając rozważania o retrotopii od przypomnienia Benjaminowskiej interpretacji słynnego rysunku Paula Klee Angelus novus z 1920 roku. Anioł w odczytaniu Waltera Benjamina chciałby uleczyć przeszłość, ale wiatr od strony raju popycha go ku przyszłości. Współczesny Anioł, jak dowodzi Bauman, obrócił się o 180 stopni i patrząc z przerażeniem na ,piekło przyszłości”, w której nie da się niczego naprawić, ulatuje ku „rajowi przeszłości”"16.

Sztuka Hachenburga jest pełna aluzji do systemu hitlerowskiego, a jednocześnie uniwersalna, może nawet bardziej aktualna obecnie — w XXI wieku, w epoce retrotopii, jak ją widzą Boym i Bauman — niż w czasie, w którym powstawała. Autor pokazał w skondensowanej i karnawałowej formie podatność ludzi na manipulację dokonywaną za pośrednictwem retrotopijnej wizji serwowanej przez autorytet. Uniwersalność tematu wynika niejako z samego medium: loutkové divadlo, zapewne najbliższe teatralnym doświadczeniom nastoletniego autora wychowanego w praskim sierocińcu, sine qua non odnosi się do powtarzalnych mechanizmów i wątków, jest zawieszone w bajkowym, ludowym albo mitycznym bezczasie. Wyrasta z nurtu karnawałowego, a więc wywrotowego, z istoty swojej opozycyjnego wobec wszelkiej zwierzchności, tyranii, hierarchii. Awangardowi twórcy w międzywojennej Czechosłowacji, poszukujący nowych form i przestrzeni artystycznych — takich jak cyrk czy sport — zainteresowali się także teatrem kukiełkowym, który okazał się podatny na rozmaite modyfika-

14 Ibidem, s. 8-9.

${ }^{15}$ Retrotopia może przybierać w określonych warunkach formę eskapizmu, tak jak to ma miejsce w innej terezińskiej sztuce Zdeňka Eliáša i Jiříego Steina Dým domova, [w:] Divadelní texty z terezinského..., s. 187.

${ }^{16}$ Z. Bauman, Retrotopia..., s. 2. 
cje $^{17}$. Artyści pokazali, że ten środek teatralnego wyrazu może adaptować nie tylko nowe charaktery, nowy - na przykład surrealistyczny — sztafaż, ale i poważne, eschatologiczne tematy, które zawsze będą groteskowo czy ironicznie kontrapunktowane przez „niepoważną” formę. Żywioł parodii jest w omawianej sztuce wielopoziomowy: podlega mu język (biurokratyczny, gwarowy, ale i żydowski żargon), rozmaite zjawiska i instytucje (SS, SA, Židovská samospráva), aluzyjne postaci (Władca, Minister, Policjant itp.). Sama forma teatru kukiełkowego, która nie jest u Hachenburga parodiowana ${ }^{18}$, ma wielki potencjał „,sensonośny” w kontekście Terezina jako miejsca, do którego się niebezpośrednio odwołuje.

Śmierć jest jednak w Hledáme strašidlo porwana czy skradziona jeszcze w innym sensie: Król odziera ją z godności, doprowadza do jej ośmieszenia, a zatem narusza tabu. Takie naruszenie zawsze odzwierciedla się w rozchwianiu systemu społecznego, będąc jednocześnie jego konsekwencją. To, co dzieje się ze śmiercią w czasie nazistowskich zbrodni, doskonale odzwierciedlają późniejsze rozważania Henryka Grynberga czy Michała Głowińskiego nad ,śmiercią godną i niegodną", do których odwołuje się Maria Janion w Aneksie o Holokauście:

Lekcja Holokaustu każe przemyśleć znaczenie śmierci cywilnej. Podział na śmierć „wartościową” i śmierć „bezwartościową” musi zostać przedefiniowany. Michał Głowiński trafnie polemizuje z opiniami „,niemądrymi i lekkomyślnymi” na temat śmierci podczas Zagłady i uważa, że trzeba wyraźnie powiedzieć, że „każdy, kto umarł ze zbrodniczych wyroków, umarł godnie"19.

Postulowana przez badaczkę w cytowanym rozdziale redefinicja dotychczasowego, utrwalonego w kulturze pojmowania śmierci jest konsekwencją „socjotechnicznych" operacji dokonywanych wcześniej przez ideologów; jednocześnie jednak postulat ten pokazuje, jak potężny zasięg ma „lekcja Holokaustu”, zasięg zarówno w sensie wpływu na kulturę, jak i czasu oddziaływania: zmiany, o których mowa, zachodzą dopiero teraz, lata po wojnie. W odniesieniu do omawianej sztuki można by powiedzieć, że godność śmierci, skradziona przez uzurpatorów,

17 Teatr kukiełkowy, nieco zapomniany od czasu dziewiętnastowiecznego czeskiego inscenizatora Matěja Kopeckiego, w dwudziestoleciu międzywojennym znów miał swój złoty okres. Obok tradycyjnych charakterów, z których najważniejszy był Kašparek (spokrewniony z Hanswurstem, czyli Honcbuřtlem, czyli Zamim (Jasiem) z commedia dell'arte, spokrewnionym z kolei ze średniowiecznym Błaznem, francuskim Sotem, Głupkiem z Confrérie des Sots), występowały postaci nowe, aluzyjne i aktualne. Nie inaczej jest u Hachenburga: Honzie, który gra rolę Kašparka-Zamiego, towarzyszą Żyd, Policjant, Minister, a zatem charaktery wywodzące się z nowych czasów i nowego miejsca, w którym autor sztuki musiał zamieszkać. V. Černý, Barokní divadlo v Evropě, Praha 2009, s. 213.

18 Zob. I. Osolsobě, Principia Parodica totiž Posbirané papiry převážně o divadle, Praha 2007, s. 43. Autor wskazuje, że parodia nie jest osobnym gatunkiem, lecz jedynie formalnie odnosi się do tego, co ma zostać sparodiowane. Jeśli sparodiowany ma być język, to trzeba to zrobić w języku, jeśli opera - to w operze itp.

${ }^{19}$ M. Janion, Aneks o Holokauście. Śmierć „godna” i „niegodna”, [w:] Bohater, spisek, śmierć. Wyktady żydowskie, Warszawa 2009, s. 123. 
dopiero teraz jest ofiarom przywracana. Maria Janion nawiązuje w przytoczonym fragmencie do słów zapisanych przez Michała Głowińskiego w Czarnych sezonach. Polemizując z koncepcją „śmierci niegodnej”, autor opisuje także kategorię „śmierci żydowskiej”, równie sztuczną i krzywdzącą jak ,śmierć niegodna”, i podobnie jak ona - skonstruowaną przez ideologów, „złodziei śmierci”. Wspominając jednego z ludzi poznanych podczas wojny, Głowiński podsumowuje: ,zginął nie jako Żyd, co w tym okresie wydawać się mogło niezwykłe lub wręcz paradoksalne, a ktoś taką śmierć byłby gotów nawet potraktować jako przejaw ironii losu, naruszającej porządek rzeczy ustanowiony w czasach Zagłady"20.

Hanuš Hachenburg nie dożył końca wojny, ale ostatnie sceny jego sztuki mogą być interpretowane jako prognoza stanu społeczeństw po jej zakończeniu, wizja postkatastrofizmu. $Z$ tego pożaru, zdaje się mówić autor, nikt nie wyjdzie nieosmalony; raz zaburzonego etycznego porządku świata nie da się ani zatrzymać, ani odwrócić, ani w krótkim czasie naprawić. Król nie docenia zdolności adaptacyjnych swoich poddanych: okazuje się, że na lęk przed Śmiercią - codzienną, odartą z wielkości i dostojeństwa - można się uodpornić. Kostucha ${ }^{21}$ obnoszona po ulicach nie budzi już grozy, a skoro ona nie wystarcza, sam Król musi zająć jej miejsce jako Straszydło. To oznacza klęskę retrotopicznej logiki: skoro władca dekonspiruje się jako twórca retrotopii, nie może już występować w roli obrońcy, gwaranta powrotu do szczęśliwej przeszłości. Dewaluują się wszystkie wartości: nie ma już znaczenia ani śmierć, ani lęk, ani ludzka solidarność, bo ta już wcześniej została zerwana, podobnie jak rodzinne więzi. Nastaje absolutny etyczny chaos, symbolizowany przez taniec Króla ze Śmiercią na cyrkowej arenie - taniec przypominający walkę i dance macabre jednocześnie, w którym rozbrzmiewają jedynie słowa wzajemnych oskarżeń: „ty jesteś winien” — „ty jesteś winna”; słowa, których echo będzie słychać później podczas procesów w Norymberdze i jeszcze przez wiele powojennych lat.

\section{Bibliografia}

Artwińska A., Czapliński P., Molisak A., Tippner A., Po Zagładzie. Narracje postkatastroficzne w polskiej prozie, „Poznańskie Studia Polonistyczne. Seria Literacka” 2015, nr 25 (45).

Bauman Z., Living towards the past, „Spiked Review” 12, 2016, http://www.spiked-online.com/ spiked-review/article/living-towards-the-past/19148\#.WaSViD5Ja00 [dostęp: 27.08.2017].

Bauman Z., Modernity and the Holocaust, New York 1989.

Bauman Z., Retrotopia, Cambridge-Malden 2017.

Cizí i blizcí. Židé, literatura, kultura v českých zemích ve 20. století, red. J. Holý, Praha 2016.

Černý V., Barokni divadlo v Evropě, Praha 2009.

Divadelni texty z terezinského ghetta 1941-1945/Theatertexte aus dem Ghetto Theresienstadt 19411945, red. L. Peschel, Praha 2008.

${ }^{20}$ M. Głowiński, Czarne sezony, Warszawa 1999, s. 101.

${ }^{21}$ Czeszczyzna ma szczególne, eufemistyczne, określenie śmierci: „smrtička”, niedokładny odpowiednik polskiej „kostuchy”. Niedokładny, ponieważ zawiera element „oswojenia”, nawet pewnego zaprzyjaźnienia ze śmiercią. 
Głowiński M., Czarne sezony, Warszawa 1999.

Janion M., Bohater, spisek, śmierć. Wykłady żydowskie, Warszawa 2009.

Musil R., Über die Dummheit, http://gutenberg.spiegel.de/buch/-6885/2 [dostęp: 27.08.2017].

Osolsobě I., Principia Parodica totiž Posbirané papíry převážně o divadle, Praha 2007.

Sachs N., The Poetics of Silence and the Limits of Representation, oprac. E. Martin, Berlin 2011.

Tischner J., Świat ludzkiej nadziei, Kraków 2000.

\section{The stolen death: About the play Hledáme strašidlo by Hanuš Hachenburg from 1943}

\section{Summary}

The puppet theatre play Hledame strašidlo by Hanuš Hachenburg was written in the Terezín/ Theresienstadt ghetto in 1943 and over 50 years was hidden in the archive until it was presented to readers and viewers in the $1990 \mathrm{~s}$ - but it turned out to be still surprisingly valid and cogent. The author, a 14-year-old prisoner of the ghetto, used the conventions of the puppet theatre, the carnival and the fairy tales. The mythical or fairy-tale-like "timelessness" allowed him to show the absurdity of Nazism and - yet unnamed - the Holocaust. The main character of the play, the King, captures Death itself, which soon becomes so ordinary and kitschy that no one is afraid of her. The confinement of Death - a motif known, among others, from the myth of Sisyphus — is an important theme of the theatre in Terezín; it appears also in the German-speaking opera by Peter Kien and Viktor Ullmann, Der Keiser von Atlantis (Emperor of Atlantis). In this article, I show how the old themes of enslaved Death and the dance macabre between extasy and destruction become the symbols of the war, and indeed of the 20th century, which culminates in the devastating forces of the great ideologies and in which there can be found the origins of retrotopia, which is now, according to Zygmunt Bauman, the dominating point of view in East- and West-European and in American discourse.

Keywords: Theresienstadt, theatre, Death, retrotopia, Nazism

\section{Únos smrti. O terezínske divadelní hře Hledáme strašidlo Hanuše Hachenburga z roku 1943}

Obsah

Divadelní hra Hledáme strašidlo od Hanuše Hachenburga byla napsána v ghettu Terezín / Theresienstadt $\mathrm{v}$ roce 1943 a více než padesát let byla ukryta $\mathrm{v}$ archivu, aby v 90 . letech si našla cestu pro své čtenáře a diváky - a ukázalo se, že je překvapivě platná a přitažlivá. Autor, čtrnáctiletý vězeň ghetta, využil konvencí loutkového divadla, karnevalu a pohádek. Mýtická nebo pohádková „nadčasovost“" mu umožnila ukázat absurditu nacismu a — tehdy ještě nemenovaného - holocaustu. Hlavní postava hry, Král, zachytí samotnou Smrt, která se brzy stane tak obyčejnou a kyčovitou, že se ji nikdo nebude bát. Únos smrti — motiv známý mimo jiné i z mýtu Sisyfa — je důležitým tématem divadla $\mathrm{v}$ Terezíně; objevuje se také v německojazyčné operě Petera Kiena a Viktora Ullmanna Der Keizer von Atlantis (Císař Atlantidy). V tomto textu ukazuji, jak se staré motivy zotročené Smrti a danse macabre mezi extázi a zničení stávají symbolem války a celého 
dvacátého století, v který vyvrcholily ničivými sily velké ideologie a kde lze nalézt počátky retrotopie, která je podle Zygmunta Baumana dominantním hlediskem ve východním, západoevropským a americkým diskurzu.

Klíčová slova: Terezín, divadlo, Smrt, retrotopie, nacismus 